\title{
Psychosocial factors in nursing work and occupational risks: a systematic review
}

\author{
Fatores psicossociais no trabalho da enfermagem e riscos ocupacionais: revisão sistemática \\ Factores psicosociales en el trabajo de enfermería y riesgos laborales: revisión sistemática
}

Patrícia Carneiro Pessoa Pousa' ORCID: 0000-0002-1997-0301

Sérgio Roberto de Lucca' ORCID: 0000-0001-6023-0949

'Universidade Estadual de Campinas. Campinas, São Paulo, Brazil.

How to cite this article: Pousa PCP, Lucca SR. Psychosocial factors in nursing work and occupational risks: a systematic review.

Rev Bras Enferm. 2021;74(Suppl 3):e20200198. doi: http://dx.doi.org/10.1590/0034-7167-2020-0198

Corresponding author:

Patrícia Carneiro Pessoa Pousa pcp.pousa@gmail.com

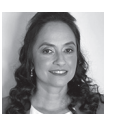

EDITOR IN CHIEF: Antonio José de Almeida Filho ASSOCIATE EDITOR: Fátima Helena Espírito Santo

Submission: 05-08-2020

Approval: 09-23-2020

\begin{abstract}
Objective: to identify, in international scientific production, the main psychosocial factors in nursing work, found through the Copenhagen Psychosocial Questionnaire (COPSOQ) application. Methods: a systematic review study of psychosocial factors at work among nursing professionals, who used COPSOQ in the assessment of work environments. Results: fifteen articles were identified, which highlighted as main psychosocial dimensions of nursing work demands, work organization, social relationships and leadership, work-home interface, workplace health and well-being and offensive behaviors. Conclusion: the high demands for cognitive, emotional work and work pace were identified in the nursing routine. Management support had a positive impact. Physical and psychological violence and shift work interfere in family life, aggravating the fatigue of these professionals. Interventions for reducing work stress presuppose the identification of psychosocial factors involved in nursing work. Descriptors: Nursing; Work; Occupational Health; Occupational Risks; Mental Health.
\end{abstract}

\section{RESUMO}

Objetivo: identificar, na produção científica internacional, os principais fatores psicossociais no trabalho de enfermagem, encontrados por meio da aplicação do instrumento Copenhagen Psychosocial Questionnaire (COPSOQ). Métodos: estudo de revisão sistemática dos fatores psicossociais no trabalho entre profissionais de enfermagem, que utilizaram o COPSOQ na avaliação dos ambientes laborais. Resultados: foram identificados 15 artigos, que destacaram como principais dimensões psicossociais da enfermagem as exigências laborais, a organização do trabalho, as relações sociais e liderança, interface trabalho-casa, saúde e bem-estar no local de trabalho e comportamentos ofensivos. Conclusão: as elevadas demandas de trabalho cognitivas, emocionais e ritmo de trabalho foram identificados no cotidiano da enfermagem. $\mathrm{O}$ suporte das chefias teve impacto positivo. A violência física e psicológica e o trabalho em turnos interferem na vida familiar, agravando a fadiga desses profissionais. As intervenções para a redução do estresse laboral pressupõem a identificação dos fatores psicossociais implicados no trabalho da enfermagem.

Descritores: Enfermagem; Trabalho; Saúde do Trabalhador; Riscos Ocupacionais; Saúde Mental.

\section{RESUMEN}

Objetivo: identificar, en la producción científica internacional, los principales factores psicosociales en el trabajo de enfermería, encontrados mediante la aplicación del Copenhagen Psychosocial Questionnaire (COPSOQ). Métodos: estudio de revisión sistemática de los factores psicosociales en el trabajo entre profesionales de enfermería, quienes utilizaron COPSOQ en la evaluación de ambientes laborales. Resultados: se identificaron 15 artículos, los cuales destacaron como principales dimensiones psicosociales de las demandas laborales de enfermería, organización del trabajo, relaciones sociales y liderazgo, interfaz trabajo-hogar, salud y bienestar en el lugar de trabajo y conductas ofensivas. Conclusión: se identificaron las altas demandas de trabajo cognitivo, emocional y ritmo de trabajo en la enfermería diaria. El apoyo a la gestión tuvo un impacto positivo. La violencia física y psicológica y el trabajo por turnos interfieren en la vida familiar, agravando el cansancio de estos profesionales. Las intervenciones para reducir el estrés laboral presuponen la identificación de los factores psicosociales involucrados en el trabajo de enfermería.

Descriptores: Enfermería; Trabajo; Salud Laboral; Riesgos Laborales; Salud Mental. 


\section{INTRODUCTION}

Nursing is considered an essential and central profession in the structure of health professions, present in all organizational units of the health system ${ }^{(1)}$. The characteristics of work in organizations is a complex, multifactorial phenomenon and studied in several economy sectors ${ }^{(2-3)}$, being little studied in the fields of health and nursing. In the health sector, this phenomenon impacts the quality of care provided, affecting workers and users. Health professionals can leave work because of problems related to management and working conditions, especially in nursing, due to lack of working conditions and overload of activities, as well as the growing increase in workplace violence and bullying ${ }^{(4)}$.

Work organization is a source of stress due to the rigid organizational structure of health services. Specifically in the hospital environment, the intense demand, the pace of work, the low autonomy and the double shift due to the low minimum wage impact on physical and mental wear and burnout syndrome of workers ${ }^{(5)}$. nursing is one of the professions most exposed to occupational stress due to exposure to psychosocial factors, such as workload, high work pace and lack of autonomy nursing is one of the professions most exposed to occupational stress due to exposure to psychosocial factors, such as workload, high work pace and lack of autonomy nursing is one of the professions most exposed to occupational stress due to exposure to psychosocial factors, such as workload, high work pace and lack of autonomy ${ }^{(1,4)}$.

Psychosocial factors at work are among the main triggers of stress, however studies carried out in the field of health and also in the field of nursing on working conditions are scarce and focused on sharp work accidents and ergonomic work conditions $s^{(5-6)}$. This article is relevant because it contributes to the construction of knowledge about psychosocial factors in nursing practice settings, based on analysis of scientific production that used the Copenhagen Psychosocial Questionnaire (COPSOQ) to identify the main psychosocial factors in nursing work.

Psychosocial factors at work (PFW) were described by international agencies as one of the main factors that trigger stress and psychological illness among workers ${ }^{(7)}$. The European Agency for Safety and Health at Work understands that organizations need to assess and manage psychosocial factors. PRIMA-EF (The European Framework for Psychosocial Risk Management) is a reference guide on the main psychosocial risk factors ${ }^{(7)}$, such as content, load, pace and working hours, control, environment and equipment, organizational culture and functioning, interpersonal relationships at work, organization's role, career development and work-home interface.

To know the primary causes of stress, it is necessary to know the PFW. For its identification, theoretical models and instruments have been developed that assess, in the perception of the organization's workers, the existence of psychosocial factors, which may have a risk or protection character. Among the various instruments, validated for their psychometric properties, $\mathrm{COPSOQ}^{(8)}$, since its first version, due to its wide range of aspects, in a multidimensional perspective, is the most used instrument in the international community for PFW assessment. In this way, it allows the comparison of results between organizations and countries in their respective versions of cross-cultural validation ${ }^{(9-10)}$.
This work aimed, based on a systematic literature review, at analyzing the scientific production that used COPSOQ to identify the main PFW of nursing, with an impact on the health of these professionals.

\section{OBJECTIVE}

To identify, in international scientific production, the main psychosocial factors in nursing work, found through the Copenhagen Psychosocial Questionnaire application.

\section{METHOD}

\section{Ethical aspects}

As it is a study of systematic review of scientific production, the need to register the research with the Brazilian National Research Council (Conselho Nacional de Saúde), and the Informed Consent Term application does not apply.

\section{Design, period, and place of study}

This literature systematic review followed the PRISMA recommendations. A systematic search was carried out in the databases in digital format PubMed to identify the scientific publication in international journals, with no time limit for the search period, in order to reach all publications made on the theme" psychosocial factors at work among nursing professionals". The choice for this database was due to its scope in international publications, since the scope and use of COPSOQ in the international setting would cover publications relevant to the subject.

\section{Population or sample; inclusion and exclusion criteria}

To obtain the universe of study, the designating expressions ["PSYCHOSOCIAL FACTORS"AND"COPSOQ"] were used. A universe of 91 articles published between January 2010 and November 2019 was obtained. The 91 abstracts of these articles were read separately by two researchers to identify those who included nursing in the research sample. Fifteen studies were identified using the PubMed search tool and 12 studies were available in the MEDLINE database.

Inclusion criteria in this study were articles published in English, Spanish or Portuguese, available in full, that used any version of the COPSOQ instrument (used in the COPSOQ I or II validations and in the short, medium or long versions) for measurement of psychosocial factors, which were related to the theme of the study and to data analysis on psychosocial factors at work and published until November 30, 2019. COPSOQ I and II have three versions of the instrument: the long version for researchers (with 128 questions on 41 scales); the medium version, for occupational health and safety professionals (with 87 items on 28 scales); the short version, to be applied in the workplace (with 40 items on 23 scales) with less than 25 workers.

The main COPSOQ II dimensions are described below:

- Quantitative demands: cognitive, emotional, to hide emotions, sensory, for responsibility at work;

- Influence on the work process and degree of freedom at work;

- Possibility of development and the meaning and job satisfaction; 
- Responsibility at work and commitment to the workplace, predictability, clarity and conflict of role;

- Quality of leadership, social support, feedback at work and social relations, sense of community, job insecurity;

- Overall health and mental health, vitality, behavioral stress and somatic and cognitive stress, sense of coherence;

- Problem-focused coping, selective coping and resignation coping.

\section{Study protocol}

Registration in the PROSPERO system was carried out to register the study protocol, however, currently, registrations for scope reviews, literature reviews or mapping reviews are not accepted. Message received when registering: "Therefore, PROSPERO cannot accept your application or provide a registration number. This decision should not prevent you from submitting your project for publication in a journal".

\section{Analysis of results}

Identifying the psychosocial factors present in the work settings of nursing professionals was mapped from the comparison with the categories established in COPSOQ: labor requirements; organization of work and content; social relations and leadership; work-home interface; values in the workplace; health and wellness; offensive behavior. Individual factors (age and gender) were also coded. The information obtained was identified and analyzed.

\section{RESULTS}

The 15 works that met the inclusion criteria totaled 8,171 participants, of which 5669 nursing professionals and 2502 other health workers (physicians and caregivers). Works from 11 countries in Europe and Asia were identified. There was a growth trend on the topic researched. In 2019, four articles were published.

The main psychosocial dimensions identified in these studies were: "Labor requirements" (13 studies); "Work organization and content" (9 studies); "Social relations and leadership" (8 studies); "Work-home interface" (5 studies); "Health and well-being" (5 studies); "Values in the workplace" (4 studies); "Offensive behavior" (2 studies). In addition to COPSOQ, in eight articles, other instruments were also applied. The results of the publications selected in this review are described in Chart 1.

Chart 1 - Identification of articles regarding authorship, year, nationality of publication, number of subjects, type of study, Copenhagen Psychosocial Questionnaire dimensions used and main results

\begin{tabular}{|c|c|c|c|c|c|}
\hline & Reference & $\begin{array}{c}\text { Year } \\
\text { Country }\end{array}$ & $\begin{array}{l}\text { Outlining/ } \\
\text { sample }\end{array}$ & COPSOQ dimensions & Main results obtained \\
\hline 1 & $\begin{array}{l}\text { Freimann } \\
\text { et al. } .^{(11)}\end{array}$ & $\begin{array}{l}2015 \\
\text { Estonia }\end{array}$ & $\begin{array}{l}\text { Cross-sectional. } \\
\mathrm{n}=404 \\
\text { Nurses }\end{array}$ & $\begin{array}{l}\text { Requirements (quantitative/emotional } \\
\text { demands/hide emotions); meaning } \\
\text { of work; social relationships and } \\
\text { leadership (rewards/gratuities/clarity of } \\
\text { roles); values in the workplace (trust). }\end{array}$ & $\begin{array}{l}\text { Sense of work, clarity of role, social relationships, mutual } \\
\text { trust among workers were protective factors. Among the } \\
\text { negative factors that refer to "hide" demands are emotions, } \\
\text { cognitive and emotional, work pace, stress and exhaustion. }\end{array}$ \\
\hline 2 & $\begin{array}{l}\text { García- } \\
\text { Rodríguez } \\
\text { et al. }{ }^{(12)}\end{array}$ & $\begin{array}{l}2015 \\
\text { Spain }\end{array}$ & $\begin{array}{l}\text { Cross-sectional } \\
\text { with stratified } \\
\text { random } \\
\text { sampling } n=498 \\
\text { Health workers* }\end{array}$ & $\begin{array}{l}\text { Requirements (cognitive/emotional } \\
\text { and sensory demands); possibility of } \\
\text { development at work/sense of the } \\
\text { importance of work); social relations } \\
\text { and leadership. }\end{array}$ & $\begin{array}{l}\text { Sample with high levels of psychological, cognitive } \\
\text { and emotional demands and possibilities for personal } \\
\text { development and sense of work. The psychosocial } \\
\text { environment was more unfavorable for the primary care } \\
\text { team, although all groups have high levels of symptoms } \\
\text { related to stress. }\end{array}$ \\
\hline 3 & Ilic et al. ${ }^{(13)}$ & $\begin{array}{l}2017 \\
\text { Serbia }\end{array}$ & $\begin{array}{l}\text { Cross-sectional } \\
\mathrm{n}=168 \\
\text { ( } 80 \text { nurses and } \\
88 \text { physicians) }\end{array}$ & $\begin{array}{l}\text { Requirements } \\
\text { (emotional and cognitive demands); } \\
\text { meaning of work and autonomy; } \\
\text { health and wellness (stress/burnout } \\
\text { syndrome). }\end{array}$ & $\begin{array}{l}\text { Physicians presented greater emotional and cognitive } \\
\text { demands in relation to nurses. } \\
\text { Both groups had high sensory demands and responsibility } \\
\text { at work, despite the low degree of autonomy. The meaning } \\
\text { of work, commitment to the workplace and job insecurity } \\
\text { were high in both groups. The risk of patient-related } \\
\text { burnout syndrome was high in both groups. }\end{array}$ \\
\hline 4 & Li et al. ${ }^{(14)}$ & $\begin{array}{l}2010 \\
\text { China }\end{array}$ & $\begin{array}{l}\text { Longitudinal } \\
\mathrm{n}=3,088 \\
\text { Nurses }\end{array}$ & $\begin{array}{l}\text { Labor requirements (emotional } \\
\text { demands); meaning and commitment } \\
\text { at work; leadership (social support and } \\
\text { feedback). }\end{array}$ & $\begin{array}{l}\text { Positive correlation between "sense of work" with } \\
\text { "commitment to the workplace" and "interpersonal } \\
\text { relationships and leadership" with "social support" and } \\
\text { "feedback". }\end{array}$ \\
\hline 5 & $\begin{array}{l}\text { Chanchai } \\
\text { et al. } .^{(15)}\end{array}$ & $\begin{array}{l}2016 \\
\text { Thailand }\end{array}$ & $\begin{array}{l}\text { Randomized } \\
\text { controlled study } \\
n=100 \\
\text { Nurses }\end{array}$ & $\begin{array}{l}\text { Requirements (work pace); meaning } \\
\text { of work; social relationships and } \\
\text { leadership (rewards/conflicts of roles/ } \\
\text { social support from supervisors). }\end{array}$ & $\begin{array}{l}\text { The intervention resulted in a positive perception for } \\
\text { the following psychosocial factors: work pace, influence } \\
\text { at work, meaning of work, predictability, rewards, role } \\
\text { conflicts and social support. }\end{array}$ \\
\hline 6 & $\begin{array}{l}\text { Ulusoy } \\
\text { et al. } .^{(16)}\end{array}$ & $\begin{array}{c}2019 \\
\text { Germany }\end{array}$ & $\begin{array}{l}\text { Cross-sectional } \\
\mathrm{n}=366 \\
\text { Nurses }\end{array}$ & $\begin{array}{l}\text { Labor requirements; } \\
\text { social relations and leadership; } \\
\text { work-home interface; values in the } \\
\text { workplace; health and well-being. }\end{array}$ & $\begin{array}{l}\text { Nurses with experience in migration are less exposed to } \\
\text { psychosocial burdens and demands than those without } \\
\text { experience. Lack of development opportunities was a } \\
\text { stress factor. }\end{array}$ \\
\hline 7 & $\begin{array}{l}\text { Kaltenbrunner } \\
\text { et al. } .^{(17)}\end{array}$ & $\begin{array}{l}2019 \\
\text { Sweden }\end{array}$ & $\begin{array}{l}\text { Longitudinal } \\
\mathrm{n}=260 \\
\text { Health workers* }\end{array}$ & $\begin{array}{l}\text { Requirements (work demands); work- } \\
\text { home interface (job satisfaction); health } \\
\text { and wellness (exhaustion/Burnout } \\
\text { Syndrome). }\end{array}$ & $\begin{array}{l}\text { At the beginning of the study, symptoms of exhaustion } \\
\text { and dissatisfaction were associated with high work } \\
\text { demands. After the implementation of the Lean method } \\
\text { in the perception of workers, there was an improvement } \\
\text { in working conditions, satisfaction and a reduction in } \\
\text { exhaustion. }\end{array}$ \\
\hline
\end{tabular}




\begin{tabular}{|c|c|c|c|c|c|}
\hline & Reference & $\begin{array}{l}\text { Year } \\
\text { Country }\end{array}$ & $\begin{array}{l}\text { Outlining/ } \\
\text { sample }\end{array}$ & COPSOQ dimensions & Main results obtained \\
\hline 8 & $\begin{array}{l}\text { Ulhassan } \\
\text { et al. }{ }^{(18)}\end{array}$ & $\begin{array}{c}2014 \\
\text { Sweden }\end{array}$ & $\begin{array}{l}\text { Longitudinal } \\
\text { multi-method } \\
\text { observational } \\
\mathrm{n}=201 \\
\text { Nurses and } \\
\text { nursing assistants }\end{array}$ & $\begin{array}{l}\text { Labor requirements; organization and } \\
\text { content of work; social relations and } \\
\text { leadership; values in the workplace. }\end{array}$ & $\begin{array}{l}\text { All psychosocial factors were positively affected by the full } \\
\text { Lean method implementation. }\end{array}$ \\
\hline 9 & $\begin{array}{l}\text { Dichter } \\
\text { et al. }{ }^{(19)}\end{array}$ & $\begin{array}{l}2017 \\
\text { Germany }\end{array}$ & $\begin{array}{l}\text { Cross-sectional } \\
\mathrm{n}=201 \\
\text { Health workers* }\end{array}$ & $\begin{array}{l}\text { Work-home interface; job satisfaction; } \\
\text { health and wellness; exhaustion. }\end{array}$ & $\begin{array}{l}\text { All psychosocial factors were affected in the provision of } \\
\text { care to patients with dementia. }\end{array}$ \\
\hline 10 & Park et al. ${ }^{(20)}$ & $\begin{array}{l}2015 \\
\text { South } \\
\text { Korea }\end{array}$ & $\begin{array}{l}\text { Cross-sectional } \\
\mathrm{n}=970 \\
\text { Nurses }\end{array}$ & $\begin{array}{l}\text { Requirements (quantitative demands/ } \\
\text { work rate/emotional demands); } \\
\text { values in the workplace (trust/justice); } \\
\text { offensive behaviors (violence). }\end{array}$ & $\begin{array}{l}\text { Physical violence, threats of violence and verbal abuse } \\
\text { were more frequent in ICUs, and sexual harassment and } \\
\text { bullying were higher in operating rooms. Patients, followed } \\
\text { by physicians and patients' relatives, were the main } \\
\text { perpetrators of the violence. Nurses with greater work } \\
\text { demands and less confidence and justice were more prone } \\
\text { to violence. }\end{array}$ \\
\hline 11 & $\begin{array}{l}\text { Januario } \\
\text { et al. }{ }^{(21)}\end{array}$ & $\begin{array}{l}2019 \\
\text { Denmark }\end{array}$ & $\begin{array}{l}\text { Cross-sectional } \\
\mathrm{n}=536 \\
\text { Health workers* }\end{array}$ & $\begin{array}{l}\text { Labor requirements (quantitative and } \\
\text { emotional demands); social relations } \\
\text { and leadership (social support/quality } \\
\text { of leadership). }\end{array}$ & $\begin{array}{l}\text { In nursing homes, workers reported greater physical effort } \\
\text { and low support from leaders. In the wards, there was a } \\
\text { predominance of high qualitative demand, high work pace } \\
\text { and low level of justice. }\end{array}$ \\
\hline 12 & Kwiatkowski ${ }^{(22)}$ & $\begin{array}{l}2011 \\
\text { Germany }\end{array}$ & $\begin{array}{l}\text { Correlational } \\
\mathrm{n}=60 \\
(30 \text { nurses } \\
\text { and } 30 \text { health } \\
\text { workers*) }\end{array}$ & $\begin{array}{l}\text { Work-home interface; possibility of } \\
\text { development and influence at work; } \\
\text { social relations and leadership (social } \\
\text { support and feedback). }\end{array}$ & $\begin{array}{l}\text { Caregivers' psychosocial stress is greater compared to } \\
\text { qualified nurses. }\end{array}$ \\
\hline 13 & $\begin{array}{l}\text { Nübling } \\
\text { et al. }{ }^{(23)}\end{array}$ & $\begin{array}{l}2010 \\
\text { Germany }\end{array}$ & $\begin{array}{l}\text { Cross-sectional } \\
\mathrm{n}=889 \\
\text { Health workers* }\end{array}$ & $\begin{array}{l}\text { Labor requirements (demands); } \\
\text { health and well-being (stress/tension); } \\
\text { organization and control (autonomy); } \\
\text { social relations and leadership } \\
\text { (support). }\end{array}$ & $\begin{array}{l}\text { Home care workers have less quantitative and emotional } \\
\text { demands, less work conflict, privacy and better } \\
\text { development possibilities. }\end{array}$ \\
\hline 14 & $\begin{array}{l}\text { Ismail } \\
\text { et al. }{ }^{(24)}\end{array}$ & $\begin{array}{c}2019 \\
\text { Jordan }\end{array}$ & $\begin{array}{l}\text { Cross-sectional. } \\
\mathrm{n}=220 \\
\text { Nurses }\end{array}$ & $\begin{array}{l}\text { Requirements (quantitative demands); } \\
\text { work-home interface (conflicts between } \\
\text { family and work); health and wellness; } \\
\text { offensive behaviors (sexual harassment/ } \\
\text { physical violence and bullying). }\end{array}$ & $\begin{array}{l}\text { Quantitative demands and sexual harassment were the } \\
\text { main predictors of all types of work-related exhaustion and } \\
\text { fatigue. }\end{array}$ \\
\hline 15 & $\begin{array}{l}\text { Carthy } \\
\text { et al. }{ }^{(25)}\end{array}$ & $\begin{array}{l}2016 \\
\text { Ireland }\end{array}$ & $\begin{array}{l}\text { Cross-sectional } \\
n=210 \\
\text { Nurses }\end{array}$ & $\begin{array}{l}\text { Labor requirements } \\
\text { (cognitive demands). }\end{array}$ & $\begin{array}{l}\text { Nurses with a high quantitative demand for work were } \\
\text { more involved in healthy life activities than the same } \\
\text { professionals aged } 40 \text { and over. }\end{array}$ \\
\hline
\end{tabular}

Note: COPSOQ: Copenhagen Psychosocial Questionnaire; *The term "health workers" was adopted because the articles do not specify the professional category, although all these articles are related to health care settings.

\section{DISCUSSION}

Psychosocial factors and the type of management in health organizations can negatively impact the health of their professionals. In the articles selected in this review, the high demands of cognitive, emotional work and of hiding emotions and work pace were identified as part of the daily life of the nursing profession during patient care and assistance ${ }^{(11-12)}$.

In hospitals, lack of autonomy and high psychological demands contribute to the nursing category being considered a high risk group for illness ${ }^{(26)}$. In primary care services, the lack of predictability and support from leaders are stressors and Burnout Syndrome ${ }^{(12)}$. The intensity of these injuries is proportional to exposure time ${ }^{(27)}$.

Health professionals are among the groups that evaluate themselves as the most affected by their psychosocial work environment ${ }^{(28)}$; however, the identification of these professionals with the type of work they perform is a motivating factor in overcoming difficulties, increasing well-being ${ }^{(29)}$. For nursing professionals, motivation and social support are protective factors against the risk of work-related mental disorders ${ }^{(12)}$.
In fact, sense, its meaning and commitment to work are intrinsic factors among these professionals ${ }^{(13-15,29-30)}$, and the meaning of work is a decisive factor, even in environments with a low degree of autonomy and high levels of insecurity, not affecting the responsibility at work of these professionals ${ }^{(13-14)}$. Moreover, development opportunities have a positive effect on health and well-being $^{(16)}$.

On the other hand, the degree of commitment of health professionals at work correlates with the availability of human resources and improves the team's performance ${ }^{(31)}$. Having few resources was associated with a lack of staff disengagement ${ }^{(30,32)}$. The lack of resources in situations of high demands contributes to the increased exhaustion of health professionals ${ }^{(33-34)}$. Lean management method, adopted in some hospitals, apparently had a positive impact on patient care satisfaction ${ }^{(17-18)}$. This result was contradictory, since, in most studies, this method contributed to increase stress and exhaustion ${ }^{(35-37)}$.

The impact of psychosocial factors is of particular concern in periods of public austerity and economic recession ${ }^{(38-39)}$. In this setting, in an alarming psychosocial environment, the high psychological and emotional demands increase stress levels of 
these professionals ${ }^{(29)}$. Freimann and Merisalu ${ }^{(11)}$ identified that the occurrence of changes in the health system in Estonia brought additional pressures for nursing professionals.

Violence against health professionals is another aspect that has a negative impact on your health. A study on offensive behaviors, sexual harassment, threats of violence and physical violence itself showed that these factors were the main predictors of all types of work-related fatigue in the emergency department of a hospital in Jordan ${ }^{(19)}$. In a study on violence presence in the form of verbal abuse, followed by threats of physical violence and sexual and moral harassment, it was found that the occurrences were perpetrated by patients, physicians and family members of patients ${ }^{(20)}$.

Due to the emotional impact, physical and psychological violence is predictive of nurses'intention to leave the profession. Adequate work requirements and a reliable and fair work environment can reduce violence against nurses ${ }^{(20)}$. Trust in colleagues and managers, the perception of justice and respect and social inclusion positively impacted the psychosocial aspects of work and the mental health of workers, when verified together with the meaning of work and social relationships ${ }^{(21)}$. In places with a high level of violence, this dimension was shown to be impaired ${ }^{(16,20)}$.

In this regard, health establishments are not neutral, since the management policies developed within these organizations and the quality of their managers or leaders assume important roles in protecting and promoting the health of the health team or vice versa. Most of the selected articles emphasized the importance of leadership in relation to quality, proximity, clarity and intervention in work processes, concluding, in their findings, the extremely detrimental effects of leadership on the psychosocial work environment, directly impacting well-being of professionals ${ }^{(13-16,21-23,29-30)}$.

Lack of support, communication, social support and feedback from leadership contribute to the perception of greater physical effort, intense work pace, conflicts of team roles and feelings of injustice. Despite the negative consequences of psychosocial factors on mental health, nurses' Burnout Syndrome is neglected by managers ${ }^{(13)}$.

The shift work of health workers aggravates fatigue and musculoskeletal problems ${ }^{(24,40)}$. Work shifts also interfere with family life. The impossibility of adequate adjustments directly affects nursing professionals, whose category is made up predominantly of women who often work double hours ${ }^{(13-14,30)}$. Furthermore, lack of intermittent rest, in work situations with intense physical and emotional load, impairs recovery and may have a negative impact on the health of these professionals ${ }^{(32)}$. Furthermore, as these professionals age, they are unable to satisfactorily respond to the physical demands required in their respective work activities ${ }^{(39)}$.

For proper management of psychosocial factors in organizations, leaders need to hear health professionals about demands, assisting in team planning and redistribution of workloads ${ }^{(14,25)}$. Intervention actions such as support and positive feedback from supervisors enable greater predictability, minimizing role conflicts ${ }^{(15)}$. Moreover, it is up to the leaders to identify the team's development needs and respect the individual limitations of each professional, adapting them in activities compatible with their work capacities.
Interventions on psychosocial factors, with the active participation of the professionals involved, have a relevant impact on reducing work stress. Professionals can influence aspects related to their own demands regarding content and working conditions, for instance, the methods and tasks to be performed, time, among others ${ }^{(13,21)}$.

This review emphasized the relevance of studies on PFW and its impact on health professionals' physical and mental health, as well as the existence of interaction of these factors with individual aspects of professionals and organization. Professionals perceptions about which factors contribute to stress can have a different outcome for each individual, acquiring positive or negative characteristics depending on who experiences them.

COPSOQ is a multidimensional instrument, applicable in different work contexts, making it possible to diagnose PFW, which trigger stress in the perception of workers. The data resulting from its application make it possible to intervene in work environments and to promote workers' health and well-being.

\section{Study limitations}

Although the definition of inclusion criteria for this study is in line with what is recommended in the literature, it may, in some way, have limited the findings, since the PubMed search instrument and the MEDLINE database were chosen. Thus, journals not indexed in these databases were not included in this study. Articles published in languages other than English, Portuguese and Spanish were excluded. Although English is used in most scientific studies, publications in other languages can contribute to expand the findings.

\section{Contributions to nursing and health}

This review is relevant because it notes the low scientific production on the influence of PFW in nursing. Identifying the impact of psychosocial factors using an internationally recognized and validated instrument for application in Brazil can contribute to monitoring occupational risks among nursing workers, directly impacting their working conditions and, indirectly, the quality of care provided to patients.

\section{CONCLUSION}

High cognitive and emotional work demands and hiding emotions and work pace were identified as part of the daily life of the nursing profession. Management support, perception of justice and respect and social inclusion had a positive impact on the preservation of nursing professionals' mental health.

Physical and psychological violence was predictive of nurses' intention to abandon the profession. Shift work interferes with family life, aggravating the fatigue of these professionals.

This review identified the low scientific production on the theme worldwide, as well as the lack of national scientific production involving nursing workers.

Interventions for reducing work stress presuppose the identification of the psychosocial factors involved with the active participation of nursing. 


\section{REFERENCES}

1. Chagas D. Psychosocial risks at work: causes and consequences. Rev INFAD Psicol. 2015;2(1):439-46. doi: 10.17060/ijodaep.2015.n1.v2.24

2. Minayo Gomez C, Vasconcellos LCF, Machado JMH. A brief history of worker's health in Brazil's Unified Health System: progress and challenges. Cien Saúde Colet. 2018;23(6):1963-70. doi: 10.1590/1413-81232018236.04922018

3. Ribeiro RP, Marziale MHP, Martins JT, Galdino MJQ, Ribeiro PHV. Occupational stress among health workers of a university hospital. Rev Gaúcha Enferm. 2018;39:e65127. doi: 10.1590/1983-1447.2018.65127

4. Scozzafave MCS, Leal LA, Soares MI, Henriques SH. Psychosocial risks related to the nurse in the psychiatric hospital and management strategies. Rev Bras Enferm. 2019;72(4):834-40. doi: 10.1590/0034-7167-2017-0311

5. Dias FM, Santos JFC, Abelha A, Lovisi GM. Occupational stress and professional exhaustion syndrome (burnout) in workers from the petroleum industry: a systematic review. Rev Bras Saúde Ocup. 2016;41:e11. doi: 10.1590/2317-6369000106715

6. World Health Organization. PRIMA EF: guidance on the European framework for psychosocial risk manegament: a resource for employers and worker representatives [Internet]. WHO Library Cataloguing-in Publication. 2008 [cited 2019 Nov 30]. Available from: https://apps.who. int/iris/bitstream/handle/10665/43966/9789241597104_eng_Part1.pdf?sequence=1\&isAllowed=y.

7. International Labor Organization. Psychosocial factors at work: recognition and control. Report of the Joint ILO/ WHO Committee on Occupational Health. Ninth Session, Geneva, 18-24 Sept 1984[Internet]. Geneva. 1986 [cited 2019 May 12]. Available from: https://www. who.int/occupational_health/publications/ILO_WHO_1984_report_of_the_joint_committee.pdf

8. Lucca SR. Fatores psicossociais e saúde mental no trabalho. São Paulo: Proteção; 2019.

9. Moncada S, Utzet M, Molinero E, Llorens C, Moreno N, Galtés A et al. (2014). The Copenhagen psychosocial questionnaire II (COPSOQ II) In Spain-A tool for psychosocial risk assessment at the workplace. Am J Ind Med. 2014;57(1):97-107. doi: 10.1002/ajim.22238

10. Pejtersen J, Kristensen T, Borg V, Bjorner J. (2010). The second version of the Copenhagen Psychosocial Questionnaire (COPSOQ II). Scand J Prim Health Care. 2010;38;(3-suppl):8-24. doi: 10.1177/1403494809349858

11. Freimann T, Merisalu E. Work-related psychosocial risk factors and mental health problems amongst nurses at a university hospital in Estonia: a cross-sectional study. Scand J Public Health. 2015;43(5): 447-52. doi: 10.1177/1403494815579477

12. García-Rodríguez A, Gutiérrez-Bedmar M, Bellón-Saameño JÁ, Muñoz-Bravo C, Navajas JFC. Psychosocial stress environment and health workers in public health: differences between primary and hospital care. Aten Prim. 2015;47(6):359-66. doi: 10.1016/j.aprim.2014.09.003

13. Ilic IM, Arandjelovic MZ, Jovanovic JM, Nesic MM. Relationships of work-related psychosocial risks, stress, individual factors and burnout: questionnaire survey among emergency physicians and nurses. Med Pract. 2017;68(2): 167-78. doi: 10.13075/mp.5893.00516

14. Li J, Fu H, Hu Y, Shang L, Wu Y, Kristensen TS et al. Psychosocial work environment and intention to leave the nursing profession: results from the longitudinal Chinese study. Scand J Public Health. 2010;38(3 Suppl):69-80. doi: 10.1177/1403494809354361

15. Chanchai W, Songkham W, Ketsomporn P, Sappakitchanchai P, Siriwong W, Robson MG. The impact of an ergonomics intervention on psychosocial factors and musculoskeletal symptoms among Thai Hospital Orderlies. Int J Environ Res Public Health. 2016;13(5)464. doi: 10.3390/ijerph13050464

16. Ulusoy N, Wirth T, Lincke HJ, Nienhaus A, Schablon A. Psychosocial burden and strains in geriatric nursing: comparison of nursing personnel with and without migration background. Z Gerontol Geriatr. 2019;52(6):589-97. doi: 10.1007/s00391-018-1414-8

17. Kaltenbrunner M, Bengtsson L, Mathiassen SE, Hans Högberg H, Engström M. Staff perception of Lean, care-giving, thriving and exhaustion: a longitudinal study in primary care. BMC Health Serv Res. 2019;19(1):652. doi: 10.1186/s12913-019-4502-6

18. Ulhassan W, von Thiele Schwarz U, Thor J, Westerlund H. Interactions between lean management and the psychosocial work environment in a hospital setting: a multi-method study. BMC Health Serv Res. 2014;14:480. doi: 10.1186/1472-6963-14-480

19. Dichter MN, Trutschel D, Schwab CGG, Haastert B, Quasdorf T, Halek M. Dementia care mapping in nursing homes: effects on caregiver attitudes, job satisfaction, and burnout: a quasi-experimental trial. Int Psychogeriatr. 2017;29(12):1993-2006. doi: 10.1017/S104161021700148X

20. Park $\mathrm{M}, \mathrm{Cho} \mathrm{S-H,} \mathrm{Hong} \mathrm{H-J.} \mathrm{Prevalence} \mathrm{and} \mathrm{perpetrators} \mathrm{of} \mathrm{workplace} \mathrm{violence} \mathrm{by} \mathrm{nursing} \mathrm{unit} \mathrm{and} \mathrm{the} \mathrm{relationship} \mathrm{between} \mathrm{violence} \mathrm{and}$ the perceived work environment. J Nurs Scholarsh. 2015;47(1):87-95. doi: 10.1111/jnu.12112

21. Januario LB, Karstad K, Rugulies R, Bergström G, Holtermann A, Hallman DM. Association between Psychosocial Working Conditions and Perceived Physical Exertion among Eldercare Workers: a cross-sectional multilevel analysis of nursing homes, wards and workers. Int J Environ Res Public Health. 2019;16(19):3610. doi: 10.3390/ijerph16193610

22. Kwiatkowski B. Effects on careers caring for residents who are limited in their everyday capabilities. A comparison of several measuring points in a pilot study. Pflege Z[Internet]. 2011 [cited 2019 Nov 30];64(5):286-90. Available from: https://www.ncbi.nlm.nih.gov/ pubmed/21638876

23. Nübling M, Vomstein M, Schmidt SG, Gregersen S, Dulon M, Nienhaus A. Psychosocial work load and stress in the geriatric care. BMC Public Health. 2010;10:428. doi: 10.1186/1471-2458-10-428

24. Ismail KM, Malak MZ, Alamer RM. Psychosocial correlates of work-related fatigue among Jordanian emergency department nurses. Perspect Psychiatr Care. 2019;55(3):486-93. doi: 10.1111/ppc.12354 
25. Mc Carthy VJC, Wills T, Crowley S. Nurses, age, job demands and physical activity at work and at leisure: a cross-sectional study. Appl Nurs Res. 2018;40:116-21. doi: 10.1016/j.apnr.2018.01.010

26. Karasek RA, Theörell T. Healthy work-stress, productivity, and the reconstruction of working life. New York: Basic Books; 1990.

27. Wang C, Huang L, Li J, Dai J. Relationship between psychosocial working conditions, stress perception, and needle-stick injury among healthcare workers in Shanghai. BMC Public Health. 2019;19(1):874. doi: 10.1186/s12889-019-7181-7

28. Palenzuela P, Delgado N, Rodríguez JA. Exploring the relationship between contextual performance and burnout in healthcare professionals. Rev Psicol Organ Trab. 2019;35(2):115-21. doi: 10.5093/jwop2019a13

29. Brito-Ortíz JF, Juárez-García A, Nava-Gómez ME, Castillo-Pérez JJ, Brito-Nava E. Psychosocial factors, psychological stress, and burnout in nursing: a model of trajectories. Enferm Univ. 2019;16(2):138-48. doi: 10.22201/eneo.23958421e.2019.2.634

30. Cordioli DFC, Cordioli Jr JR, Gazetta CE, Silva AG, Lourenção LG. Occupational stress and engagement in primary health care workers. Rev Bras Enferm. 2019;72(6):1580-87. doi: 10.1590/0034-7167-2018-0681

31. Moura AA, Bernardes A, Balsanelli AP, Zanetti ACB, Gabriel CS. Leadership and nursing work satisfaction: an integrative review. Acta Paul Enferm. 2017;30(4):442-50. doi: 10.1590/1982-0194201700055

32. Oliveira LB, Rocha JC. Work engagement: Individual and situational antecedents and its relationship with turnover intention. Rev Bras Gest Neg. 2017;19(65):415-31. doi: 10.7819/rbgn.v19i64.3373

33. Lindskog P, Hemphälä J, Eklund J, Eriksson A. Lean in healthcare: engagement in development, job satisfaction or exhaustion? J Hosp Adm. 2016;5(5):91-105. doi: 10.5430/jha.v5n5p91

34. Pereira SS, Teixeira CAB, Reisdorfer E, Vieira MV, Gherardi-Donato ECS, Cardoso L. The relationship between occupational stressors and coping strategies in nursing technicians. Texto Contexto Enferm. 2016;25(4) e2920014. doi: 10.1590/0104-07072016002920014

35. Hung DY, Harrison MI, Truong Q, Du X. Experiences of primary care physicians and staff following lean workflow redesign. BMC Health Serv Res. 2018;18(1):274. doi: 10.1186/s12913-018-3062-5

36. D'Andreamatteo A, lanni L, Lega F, Sargiacomo M. Lean in healthcare: a comprehensive review. Health Policy. 2015;119(9):1197-209. doi:10.1016/j.healthpol.2015.02.002.

37. Holden RJ. Lean thinking in emergency departments: a critical review. Ann. emerg. med. 2011;57(3):265-78. doi: 10.1016/j. annemergmed.2010.08.001

38. Soriano-Tarín G, Villaplana-García M. Corporate restructuring processes and their impact on psychophysical health in a working population: "PREISAP study". Rev Assoc Esp Espec Med Trab. [Internet]. 2017 [cited 2019 Nov 30];26:161-77. Available from: http://scielo.isciii.es/pdf/ medtra/v26n3/1132-6255-medtra-26-03-00161.pdf

39. Ruiz-Pérez I, Bermúdez-Tamayo C, Rodríguez-Barranco M. Socio-economic factors linked with mental health during the recession: a multilevel analysis. Int J Equity Health. 2017;16:45. doi: 10.1186/s12939-017-0518-x

40. Assunção AA, Pimenta AM. Job satisfaction of nursing staff in the public health network in a Brazilian capital city. Cien Saúde Colet[Internet]. 2020 [cited 2019 Nov. 30];25(1):169-80. Available from: https://www.scielo.br/pdf/csc/v25n1/en_1413-8123-csc-25-01-0169.pdf 